merchants 3 per eent, intellectuals 6 per cent, seam. stresses, domestic helpers and other employees 10-11 per cent, farmers 22 per cent and labourers 29 per cent. The highest death-rates were noted in the 1-5 year old group and in the $20-40$ group.

\section{Immunizations in Large Cities of the United States}

IN a recent paper (Public Health Rep., 58, 1121 ; 1943), Selwyn D. Collins, head statistician, and Clara Councill, assistant statistician of the United States Public Health Service, record their study of immunization against diphtheria, smallpox, scarlet fever and typhoid fever based on a canvas of 213,931 households in 23 cities of 100,000 or more inhabitants. Their conclusions are as follows. Immunizations against scarlet fever and typhoid fever are negligible compared with those against diphtheria and smallpox. In the pre-school age immunizations against diphtheria are more frequent than vaceinations against small-pox, but after five years the reverse is true. There was considerable geographical variation in the extent of immunization against the diseases. In the north, for example, the percentages of native, foreign and coloured children of specific ages immunized against diphtheria are approximately the same, while in the south a higher percentage of the native whites is immunized than of the foreign whites or coloured.

\section{Cattle Fodder from Wood}

According to an annotation entitled "Fir to Fodder" in the January issue of the Anglo-Swedish Review, the Swedish forests provide a practically inexhaustible store of timber which can be converted into fodder for horses and eattle. It can be made from the wood of the fir tree, but pine can also be used. The raw wood has no food value for man, even if ground to a fine flour, as there are no enzymes or micro-organisms in the human digestive tract to dissolve the wood and its cellulose. Cattle and horses, however, can absorb it almost entirely because their digestive organs contain bacteria which can break down the pure cellulose into products which can be absorbed into the blood. To make the fodder cellulose more nutritive and palatable to animals, molasses and sometimes phosphates or salts are added at the pulp mill. Alcohol is also obtained during the process of making fodder pulp.

\section{Research in Human Nutrition}

The Medical Research Council has established a Unit for Research in Human Nutrition as part of its staff organization, and Dr. B. S. Platt has been appointed its director. Temporary accommodation has been provided at the National Hospital for Nervous Diseases, Queen Square, London. Some part of the investigations undertaken by the Unit will be directed towards nutrition problems in the tropics. Among other things, Dr. Platt will continue the work, for which he joined the Couneil's staff in 1938, of co-ordinating a programme of nutritional investigations in the Colonies by arrangement between the Colonial Office and the Council.

\section{Properties and Uses of Diamonds}

A RESEARCH department has been established by the Diamond Trading Company, Ltd., the London office of which is at 32-34 Holborn Viaduct, London,
E.C., under the management of Mr. Paul Grodzinski, assisted by a staff of five. The Department is engaged in investigations into the properties of diamonds, their preparation for use and, in particular, their application in industry. An extensive library, built up over a long period of years by Mr. Grodzinski, forms part of the Department, and its information service is available free of charge.

\section{The Night Sky in March}

Fuls moon occurs on March 10d. 00h. 28m. U.T., and new moon on March 24d. 11h. 36m. The following conjunctions with the moon take place: March 2d. 08 h., Mars $6^{\circ}$ N. ; March 2d. 13h., Saturn $3^{\circ}$ N. ; March 7d. 11h., Jupiter $0 \cdot 1^{\circ}$ S. ; March 22d. 16h., Venus $2^{\circ}$ N.; March 29d. 23h., Saturn $2^{\circ}$ N.; March 30d. 18h., Mars $5^{\circ} \mathrm{N}$. The following occultations of stars brighter than magnitude 6 take place : March 3d. 19h. 59.4m., v Gemi. (D); March 28d. 20h. 31.1m., 63 Tauri $(D)$; March 31d. 19h. 23.5m., $\zeta$ Gemi $(D)$. The times refer to Greenwich and $D$ refers to disappearance. Mercury rises at $6 \mathrm{~h} .44 \mathrm{~m}$. and $6 \mathrm{~h} .05 \mathrm{~m}$. at the beginning and end of the month, but is too close to the sun for good observation. The planet is in superior conjunction on March 17. Venus, a morning star, rises at $5 \mathrm{~h} .34 \mathrm{~m}$. and $5 \mathrm{~h} .14 \mathrm{~m}$. at the beginning and end of the month, and can be seen only with difficulty. Mars sets at $2 \mathrm{~h}$. $54 \mathrm{~m}$. and $2 \mathrm{~h}$. at the beginning and end of the month and can be seen in the early part of the night. On March 7d. 15h. there is a conjunction between Mars and Saturn, Mars being $3 \cdot 4^{\circ} \mathrm{N}$. Jupiter is visible throughout the night, setting at $6 \mathrm{~h} .15 \mathrm{~m}$. and $4 \mathrm{~h} .13 \mathrm{~m}$. at the beginning and end of the month. Saturn is visible in the early part of the night, setting at $2 \mathrm{~h} .40 \mathrm{~m}$. and $0 \mathrm{~h} .49 \mathrm{~m}$. at the beginning and end of the month. Spring equinox begins on March 20d. 18h.

\section{Announcements}

Dr. Harry R. Ricardo, the well-known consulting engineer and authority on the internal combustion engine, has been elected president of the Institution of Mechanica] Engineers for the year 1944-45.

J. P. Rutland (New Phyt., 40, $210 ; 1941$ ) has published a supplement to the Merton Catalogue of Chromosomes of British Plants. The new list contains about a hundred new chromosome numbers discovered by the author and other workers, and is a valuable contribution to the analysis. of the British flora.

THE following appointments have recently been made in the Colonial Service: H. Doggett to be agricultural officer, Tanganyika; A. J. Browning to be assistant conservator of forests, Sierra Leone; S. L. Finding to be assistant conservator of forests, British Honduras; H. Tordoff to be assistant conservator of forests, Trinidad; A. W. Vaughan to be veterinary officer, Jamaica; Dr. E. F. Thompson to be fishery officer, Jamaica ; D. W. Duthie (chemist, British Guiana) to be soil chemist, East African Agricultural Research Bureau, Tanganyika; A. F. A. Lamb (assistant conservator of forests, Nigeria) to be senior assistant conservator of forests, British Honduras.

ERratum. In the paragraph entitled "Road Research" in NATURE of February 12, p. 193, the names of Major $\mathbf{H}$. E. Aldington (chairman) and $\mathbf{M r}$. W. Savage were inadvertently omitted from the list of members of the committee. 